\title{
Iowa's Puzzling Jeremiah Smiths
}

\author{
PhILIP D. JORDAN
}

I am indebted to John Porter Bloom, editor of the Territorial Papers of the United States and a friend of many years. Dr. Bloom furnished reams of photocopies pertaining to Jeremiah Smith, Sr. and Jeremiah Smith, Jr., although at times neither he nor I knew whether we could distinguish one from the other. William $\mathrm{O}$. Weaver, known to some as an attorney in Wapello, Iowa, to others as a local historian, and to all as an agreeable person with a fund of stories, shared his knowledge of both Smiths-and a few others thrown in for good measure. My appreciation is genuine. Once again, Margaret Cannella, Office Clerk of the District Court, Des Moines County, searched for legal records. Susie Guest and Martha Zackert, Burlington Public Library, ran files of newspapers and borrowed journals and books from other institutions. When Judith Gildner vetted the manuscript, she suggested welcomed changes, and, finally, I am also indebted to the guest editors with whom it was a pleasure to work.

\section{Introduction}

F or more than a century and a half Jeremiah Smith, Jr. was incorrectly identified as Jeremiah Smith, Sr., and Jeremiah Smith, Sr. as Jeremiah Smith, Jr. Newspapers, county histories, local, state, and federal documents, and official records frequently mistook one Smith for the other. The similarity of names has confused, baffled, and frustrated authors, editors, librarians, archivists, and historians interested in Iowa history. Some 
assumed that Jeremiah Smith, Sr. was the father or uncle of Jeremiah Smith, Jr., but that is incorrect. Jeremiah Smith, Jr. made it clear that Jeremiah Smith, Sr. was a cousin - "a distant connexion"-with whom he was acquainted for many years. ${ }^{1}$

In order to distinguish one Jeremiah Smith from the other, the two agreed to add a "Senior" after the name of one and a "Junior" after the name of the other, although Smith, Sr. possibly was younger than Smith, Jr. Unfortunately, the two did not always adhere to the agreement and all too frequently other persons spoke or wrote only of Jeremiah Smith, omitting the Senior or Junior, so that it is necessary to determine which of the two is meant. At times, even though the qualifying terms were used, signatures were written so poorly that it is difficult, if not impossible, to decipher the squiggle after a name. Then one must rely upon one's knowledge of the activities of the men and seek clues within documents. Even so, in a few instances, one is compelled to make an educated guess. Now and again, that is impossible, so confused is the available evidence. ${ }^{2}$

This article seeks to clarify misapprehensions, set the record straight, distinguish between the activities and characters of Smith, Sr. and Smith, Jr., and finally to relate details of a fraud, beginning in Iowa and reaching to Washington City, by which Smith, Sr. swindled Smith, Jr. Jeremiah Smith, Jr. was an Indian trader, politician, and resident of Burlington, Iowa. Jeremiah Smith, Sr. was the operator of a federal government mill, a trader without a license, a sometime resident of Burlington and later a resident near Locust Grove, not too far from Fairfield in Jefferson County, Iowa. The former died in Burlington. The latter, hunted by United States marshals, disappeared. Despite exhaustive search, efforts to learn what happened to him have been to no avail. Indeed, his life needs further investigation.

This author makes no claim that his account is complete and correct in every detail, although he has attempted to be as complete and accurate as possible. He hopes that publication will stimulate others to point out errors of fact and interpretation and to supply further information. 
II. Jeremiah Smith, Jr.

Jeremiah Smith, Jr. was born March 23, 1802 in Pickaway County, Ohio, where his family paid taxes in 1810 and six years later sold a hundred acres. No Jeremiah Smith, either senior or junior, was listed in the Pickaway County census for $1820 .^{3}$ That was the year the Jeremiah Smith family emigrated from Ohio to Greene County, Illinois, where, it is said, they settled on section 33, township 12, range 12. A Jeremiah Smith was a member of the county commissioner's court in September, 1826 , and, in 1832, the town of White Hall was surveyed and platted by a Jeremiah Smith, who then was a deputy county surveyor. ${ }^{4}$

Whether the Jeremiah Smith mentioned above was Jeremiah Smith, Jr. is uncertain, but it is true that Smith, Jr. of Greene County, was living in the county at the time of the Black Hawk War. When Jacob Fry raised a regiment, Smith, Jr. enlisted at Beardstown, April 20, 1832, and served in the mounted rifle brigades of the second and third regiments commanded by Generals Samuel Whiteside and James D. Henry. ${ }^{5} \mathrm{He}$ was elected company captain the day he enlisted, and a morning report showed a complement of thirty-three men and thirty horses. By May 5, he held the rank of major, a title by which he was addressed for years. An historian of the Black Hawk War says that a Lieutenant Colonel Jeremiah Smith from Greene County circulated a petition declaring an unwillingness to hunt down Black Hawk. Signers were threatened with arrest, but they soon withdrew the petition and were forgiven, including Lieutenant Colonel Jeremiah Smith who "argued somewhat implausibly that he had not known what the petition contained when he signed it." Lieutenant Colonel Smith and Smith, Sr. may have been one and the same person, for he was addressed by his title. Thus, to repeat, when Smith, Jr. settled in Burlington, he was known as Major Smith, and after Smith, Sr. arrived in Iowa, he may have been known as Colonel Smith. ${ }^{6}$ The evidence is thin.

After the war, terminated by the Treaty of September 21, 1832, and the imprisonment of Black Hawk in Jefferson Barracks, 


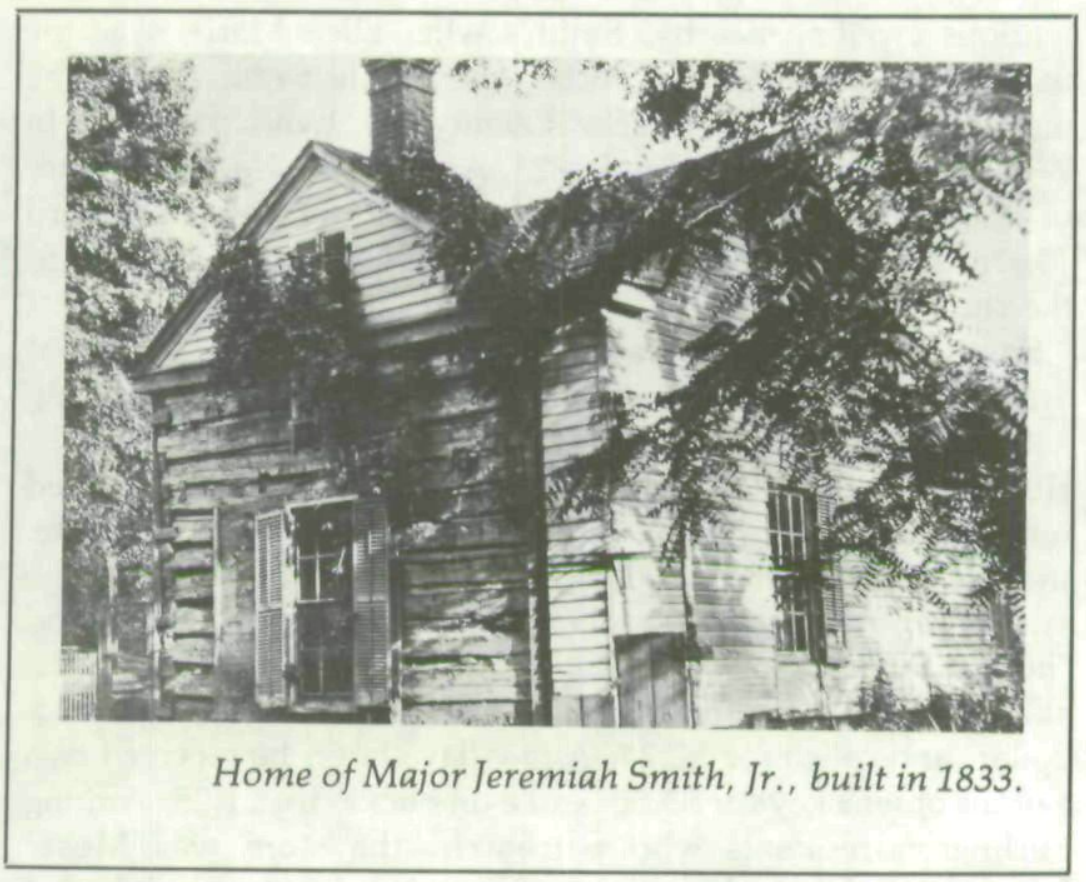

Smith, Jr., about age thirty-one, emigrated from Illinois to Burlington, then little more than a scattering of cabins. Just when or why he chose the primitive community on the west bank of the Mississippi is difficult to learn. Early settlers insist that Smith, Jr. first arrived in 1832, built a cabin about two miles "below town," and resided there with his family. If that be true, Smith, Jr. left Burlington to purchase merchandise and trade goods and returned with those supplies in the autumn of 1833, probably September. The Burlington Patriot of December 13, 1838 said that Major Jeremiah Smith came in 1833, "having sometime previously settled and improved the farm on which he at present resides, about one and a half miles from Burlington." It seems unreasonable to assume that he would have selected Burlington as a place to establish a business without first informing himself of the area or visiting it. ${ }^{7}$

Smith, Jr. also acquired a lot on Front Street in addition to the land on the prairie outside the town limits on the west. Having built a cabin on his country property, he and his family resided there until he was sufficiently affluent to construct a more pre- 
tentious dwelling nearby. Smith's wife, Ellen Marie, was the daughter of Dr. Anthony Potts, who is said to have been the pioneer physician of Greene County and who practiced in White Hall, beginning about 1823 . Amelia, the eldest daughter of Major and Mrs. Smith, Jr., was born in the cabin on April 18,1835 . In later years, Amelia recalled Black Hawk's visit to the cabin residence. ${ }^{8}$

Smith, Jr. built a frame warehouse and store on his Front Street ground. Soon he was doing a flourishing business selling nails, powder, shoes, pins, sugar, coffee, tea, and yard goods. He dealt in fruit trees-apple, cherry, peach-and supplied settlers with currant bushes, bed ticking, window glass, shovels, and brooms. His ledgers and account books show the sale of " 1 pare shoes," pots, pans, crocks, fish lines, and "hookes." Black Hawk, on April 16, 1836, obtained three and a half yards of shrouding for $\$ 7.50$, beads for $\$ 11.00$, paint for a dollar, and calico for $\$ 2.25$. A few days later, he received two gallons of whiskey for $\$ 3.50$, and a tin bucket for $\$ 1.25$. Among Burlington residents who patronized the store was Moses Jourdan (Jordan), who purchased merchandise worth $\$ 11.00 .^{9}$

River boats unloaded quantities of goods which Smith, Jr. ordered from St. Louis. An invoice of August 23, 1836 shows that he purchased crosscut saws, knives and forks, butcher knives, adzes, red-handled scalping knives, and halter chains from Henry Shaw. Among other items were scarlet, green, and yellow gartering. ${ }^{10}$

There seems little doubt but that Smith, Jr. traded with the Sac and Fox as soon as his warehouse was stocked, although no trader's license was issued to him until July 5,1839 . On that date he was authorized to trade for a year with the "Sacs \& Fox Indians, at Keokuks Village, and its vicinity."11

During September and October 1838, Smith, Jr. sold Keokuk and his braves a beef at $\$ 30.00$, a tin bucket at fifty cents, tobacco at seventy-five cents, thirty-six yards of calico at $\$ 33.00$, and five horses at $\$ 55.00$. During March 1839, Keokuk received handkerchiefs, silk, calico, linen, gingham, knives and forks, butcher knives, scissors, and, among other items, razors, razor strops, and blankets. Ammoy and his braves, during April 1839, were supplied with fur hats, blankets, scissors, 
razors, and in July, in addition to other goods, received a beef, a wool hat, two "coffy" pots, thread, and a barrel of flour. The beef was priced at $\$ 16.00$ and the flour at $\$ 5.00$. Hardfish and his braves and Keokuk and his people, in 1840-no month or day recorded-took away a beef, four hogs, twelve steel traps, a saddle and a "rifle gun," at a total cost of $\$ 955.00$. Wapello purchased trade goods worth $\$ 2900.50$. By the Treaty of 1842 with the Sac and Fox, Smith, Jr. was awarded $\$ 4000.00$ in payment of debts due him from the Indians. His difficulty in securing payment is discussed later in this article. ${ }^{12}$

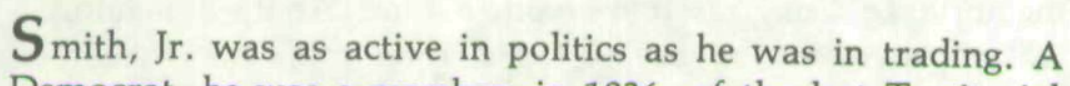
Democrat, he was a member, in 1836, of the last Territorial Legislative Council of Michigan which convened at Green Bay and which on March 1 approved payment to him of $\$ 195.00$ for his services. Near Rock Island he witnessed the signing of the Treaty of September 28, 1836 pertaining to the Keokuk Reserve, and in October represented Des Moines County at Belmont where the first, but brief Wisconsin Territorial Legislature convened. After dickering about where the temporary capital should be located, the legislators agreed upon Burlington, but only after Smith, Jr. promised to erect at his own expense a suitable capitol. ${ }^{13} \mathrm{He}$ would rent the building to the government and thus recover his investment.

True to his word, Smith, Jr. began erection of a capitol building in the summer of 1837, and the structure was completed in time for the Wisconsin Territorial Legislature to open its session on November 6 . How he financed the project is not clear, but he apparently used personal funds and did not borrow. The cost of erecting the capitol was first estimated at between seven and eight thousand dollars. Smith, Jr. did not insure the structure. It was described as "commodious, handsomely built, and well arranged for the purposes of legislation." Unfortunately, fire destroyed it and adjacent buildings, including the store of Smith, Jr., on the night of December 13. "It was," said an editor, "a sad day for Burlington and long it will be remembered in sorrow." Lawmakers, as the result of the blaze, met in two small buildings on Main Street. The first legislature of the Territory of Iowa convened on November 28, 1838 in the new 
Methodist Meeting House, soon known as Old Zion. A "very neat and substantial" building, its basement was of stone and the upper story of brick. When completed, with cupola and bell, the church would be "a great ornament and acquisition to the city of Burlington." 14

Smith, Jr. lost little time after the fire in an attempt to recover from the government monies spent in erecting the capitol. He appealed to the legislature for relief, and on December 19, 1837 both House and Council recommended that a committee of three be appointed to aid him. A joint resolution was passed to memorialize Congress to reimburse him. Another memorial was approved on January 10, 1838, three more on November 11, 13, and 25, 1839, and still another on November 19, 1840. In 1842, Iowa's territorial delegate, Augustus C. Dodge, requested a congressional appropriation of $\$ 8000.00$ to compensate Smith, Jr. "whose house had been consumed by fire while occupied by the Wisconsin Territorial Legislature in December 1837."15

Smith, Jr. knew influential individuals and kept his political fences in repair, so that he was in an excellent position to expect that favors to the party be returned. He called upon William B. Slaughter, a Virginian and attorney, who was secretary of the Territory of Wisconsin, requesting Slaughter to enlist the assistance of George W. Jones, territorial delegate to the House of Representatives. Slaughter did so. He wrote Smith, Jr. in February 1838 saying that Jones would do everything in his power to aid "and he can do a great deal in Washington." Slaughter told Jones that a good deal was due Major Smith because of his energy and enterprise in building the capitol and "still more for his patriotism in thus providing for the convenience \& comfort of the Representatives of the people." He urged Jones to exert himself to procure sufficient funds to reward Smith, Jr. "amply." 16

In 1840, after an agonizing delay, a bill was reported to the House of Representatives allowing Smith, Jr. five-eighths of the $\$ 8000.00$ for construction of the capitol at Burlington, but a Committee of the Whole House on January 16, 1841 reported the bill back with the enacting clause deleted. The matter hung fire until 1844, although Smith, Jr. and his supporters persisted 
in their efforts. In July, Henry May, attorney and later congressman from Maryland, wrote Smith, Jr., saying "Your claim is a just one \& must and shall be allowed." In October, Henry W. Starr, Burlington attorney, sent May a note supporting the claim of Smith, Jr. James Connelly, a Burlington resident, wrote Andrew Stewart, representative from Pennsylvania, urging that Smith, Jr. be reimbursed and recommending him "as an advocate for Western men and their rights. Mr. Smith's character stands high in this territory."17

Finally, the House Committee on Claims got around to considering the request of Smith, Jr. for compensation. On February 15,1845 , the Committee rejected the claim. The petitioner was not entitled to relief. Joseph Vance, a representative from Ohio, explained why. His argument lays to rest a long misunderstanding.

The principle which governs this case is very simple, and one which cannot be safely departed from, so long as this government continues to rent so large a number of buildings in different and distant parts of our widespread country. When a building is rented by the government, the United States never insures it against destruction unless through competent authority it expressly and specifically agrees to do so. The owner knows when he rents it, to what dangers it will be exposed, and of course charges for its use such sum as will justify him in insuring the house himself, or of hiring somebody to insure it for him; he, therefore, can have upon the United States neither a legal or an equitable claim for remuneration for a building accidentally or otherwise destroyed, in time of peace, when in the occupancy of the government.

May, after reading Vance's decision, thought there still was a chance to recover if Smith, Jr. could "make it appear that the Government authorities agreed to insure the building." 18

Although discouraged and angry, Smith, Jr. did not permit the denial of his claim to interfere with numerous other activities. After the Sac and Fox Treaty of 1836, he harbored hopes that he might be appointed receiver of the land office when one was established in Burlington. He, like other settlers, urged the government to open land for sale as soon as possible. On January 19, 1836, before the treaty was negotiated, Smith, Jr. 
was among those who petitioned Congress to make provision for putting land into the hands of the people.

The memorial he signed pointedly said a land office was needed and that "it is not only the present lands of the Government that will justify establishing of an office of the kind mentioned but there lies West of the late purchase an almost unbounded extent of very valuable country which to the Indians is but of little value in consequence of there being but little game." The petitioners drew attention to the fact that the Black Hawk Purchase of 1832 resulted in a rapid increase of population so that "there scarcely, between the Mississippi River and the purchase line, remains a good farming situation that is unoccupied and this is not only back of the flourishing Town of Burlington, but from the lower end of the purchase one hundred \& fifty miles upward." The Burlington land office finally became a reality, but, when it was established, Augustus Caesar Dodge was appointed receiver on June $18,1838 .{ }^{19}$

Throughout the 1830s and 1840s, Smith, Jr. invested heavily in land. During April and May 1837, for example, he purchased thirty lots in Burlington and had them surveyed. In 1836 and 1837 , he is said to have platted Lower Wapello, Louisa County, and was one of the original proprietors of the town, although he did not settle there. On December 25, 1844, he and his wife sold a portion of two tracts in Louisa County to James McDaniel for $\$ 300.00$, and previously, on August 27, sold McDaniel "all of my interest included in the original town plat of Lower Wapello, Louisa county, Iowa Territory, situated on lots 1 and 2 of the southwest quarter of section 35 , township 7 north, range 3 west, as laid off by me and others in the year 1836 and 7, and as by reference to such plat at the land office will appear." Incidentally, Smith, Jr., like other owners of land, found that pioneers, eager for timber, thought nothing of felling trees and carrying away wood not their own. Exasperated by such actions, he inserted the following in the Iowa Territorial Gazette and Burlington Advertiser on December 21, 1839: "Notice: I hereby forewarn all persons from cutting, hauling away, or in anywise destroying Timber on my land, as I am 
determined to prosecute them to the extent of the law for every such trespass hereafter."20

Smith, Jr. also owned property lying along Boundary Street, which, as the name suggests, marked the western limits of Burlington. Until 1841 the community lacked a cemetery, burials being made in any convenient place. The half-breed M. Blondeau, for example, was interred in front of S. S. Ross's store near the river front. Smith, Jr., realizing that growing Burlington no longer should bury the dead in casual manner, proposed that an area be set aside for a graveyard and offered to donate land adjacent to Boundary Street for use as a cemetery. ${ }^{21}$

City fathers accepted the gift on June 15, 1841 and employed two men to survey the five-acre tract. Each was to be paid one dollar. The surveyors first named did not perform, and the work was done by a M. Ritmer. Originally, the Smith Cemetery was an attractive area covered with trees, underbrush, and wild flowers. But much to the disappointment of the donor, it rapidly fell into disrepair. Grass was not cut, graves were untended, and, lacking a fence, animals grazed and uprooted monuments. The place, commented an editor, "is a disgrace to our city. Some of our most esteemed and earliest settlers lie there." 22

When the Hodge brothers, convicted murderers, were hanged in July 1845 , it was planned to bury their bodies in the Smith Cemetery, and William H. Brown, a gravedigger remembered the result. "I dug the graves for the Hodges, who were hung in Patterson's hollow near the road which leads to the Fair ground. The authorities would not let them be buried here, their offense and end were so fearful, so they were taken to Nauvoo and buried, when the authorities had them taken up and buried somewhere." 23

About five hundred bodies were interred in the Smith Cemetery by 1852 when the city declared the graveyard a nuisance, forbade further burials, and ordered that corpses be exhumed and reburied in Aspen Grove, a new cemetery incorporated on January 3,1844 . Removal was haphazard and careless. Workmen in 1868 ploughed up bones of persons "buried in the old cemetery donated by Major Smith." When a high school was 
being built in 1908 citizens said it was not uncommon to see human bones lying about. ${ }^{24}$

Smith, Jr., in addition to his political career, trading with the Sac and Fox, buying and selling land, building a capitol and attempting to recoup his loss when it burned, and donating ground for a cemetery, also tilled the soil surrounding his cabin. He did odd jobs and at least twice ran afoul of the law. During his residence in Burlington both his home and activities frequently were mentioned in the press as evidenced by this notice “. . . for green blanket coat lost between Burlington and Major Smith's" which appeared in the Iowa Territorial Gazette and Burlington Advertiser on July 28, 1838. This was followed on March 23, 1839 by a notice from Smith, Jr.: "All persons indebted to me by note on account, are hereby notified that all demands over Fifty Dollars are deposited with M. D. Browning, Esq., and all less than fifty with David Hendershott, Esq. Those wishing to save costs, can do so by calling on either of the above named persons and pay the same, who are authorized to receive and receipt in my name. I will pay all costs that may accrue if the money is paid before judgment obtained." On December 31, 1840, a prominent Burlington resident, William B. Remey, reported in the Hawk-Eye and lowa Patriot the loss of a black silk cape, a fine, white muslin collar, and a breast pin all "rolled in a news-paper" between the city and Major Smith's. ${ }^{25}$

The life of Smith, Jr. would have been less complicated and his problems fewer had it not been for the coming to Burlington of Jeremiah Smith, Sr., the cousin whom Smith, Jr. referred to as a distant connection. ${ }^{26}$

III. Jeremiah Smith, Sr.

On June 1, 1838, Smith, Sr. met in Burlington with Joseph M. Street, agent for the Sac and Fox Agency situated near Ottumwa in Wapello County. They signed a contract by which Smith, Sr. agreed to construct two grist mills for which he was to receive $\$ 5000.00$. One mill was to be built on the waters of 
the Des Moines River and another on the Iowa, Red Cedar, or Des Moines rivers as determined by Street. ${ }^{27}$

The agreement between Street and Smith, Sr. was most specific as to how the mills were to be built. Foundations of dams were to be three feet deep and the dams themselves eighteen feet wide. Cross ties were to stand ten feet apart and notched down close with other timbers to form pins six by ten feet. Space between cross ties must be filled with rock, and "if rock cannot be conveniently got to the place the pins to be filled with clay and brick well pounded in." Street specified that the front or upper side of each dam must be protected with straight-hewed split puncheons "to prevent the crawfish from making holes." He said that aprons below dams were to be fashioned of split puncheons or sound poles "well fashioned down and secured." Abutments should extend well into stream banks and rise three feet above the tumble of the dams. Smith, Sr. learned that good, durable timber was a necessity. Mill stones were to be three and a half feet in diameter, water wheels were to be thoroughly seasoned, and the rounds and cogs of wheels were to be of seasoned dogwood or hickory.

The contract between Street and Smith, Sr. stipulated that the latter was to build near each dam a house in which the miller should live. Each house was to be "twenty by twenty four feet of hewed logs covered with oak or Walnut shingles and placed on a firm foundation, having in view their exposed situation in times of freshets or breaking up of ice in the spring." Floors must be fashioned from oak planks. In addition to two glass windows, a miller's house was to be fitted with "one door with plank shutters hung with strong Iron hinges and a pad lock to each door."

Street reserved the right to remove Smith, Sr., the contractor, and any workmen employed by him, from the "Indian country" if their conduct proved injurious to the Sac and Fox, to the government, or was in violation of the law. In the event of failure or deficiency on the part of Smith, Sr., Street "could supply the deficiency, and the said Jeremiah Smith, Senior hereby agrees to forfeit fifty percent of the amount of said failure." Construction was to be completed by October $1 .{ }^{28}$ 
Two grist mills were erected for the use of the Sac and Fox, one on Sugar Creek, about two miles below Ottumwa on the north side of the Des Moines River, and another on Soap Creek on the south side of the Des Moines. The Soap Creek mill was in charge of Major Samuel Smith of Burlington, not to be confused with Major Jeremiah Smith, Jr. Smith, Sr. operated the mill on Sugar Creek and opened a large farm near the mill. At times he also interested himself in what was known as the Appanoose Creek mill. Indeed, Governor Robert Lucas appointed Smith, Sr. miller of the Appanoose Creek mill on May 9, 1839 and the appointment was approved on June 13.

Relations between Smith, Sr. and Lucas were cordial enough, for the former was among those who found it easy to approach the latter. Smith, Sr. also was among those who signed Street's bond as Indian Agent for Iowa's Sac and Fox. The bond, in the amount of $\$ 20,000$, was signed on May 6, 1839. When T. Hartley Crawford, Federal Commissioner of Indian Affairs, learned that a Jeremiah Smith was appointed a miller, he wrote Lucas inquiring if the miller was the same Jeremiah Smith who was granted a trader's license on July 5, 1839.

If the two Smiths, Crawford told Lucas, were one and the same person, then Lucas had violated the law which specified that no person employed by the Indian Department "shall have interest or concern in any trade with the Indians, except for, and on account of the United States." If, Crawford repeated, Smith the miller and Smith the trader were one and the same person, then Lucas must name another person as miller or revoke the license of the trader. Once again, as happened previously and was to occur again and again, the Jeremiah Smiths were confused. It was Smith, Sr. whom Lucas named miller, and not Smith, Jr. who was the licensed trader. Lucas had made no mistake. ${ }^{29}$

Soon after construction, the Sugar Creek mill managed by Smith, Sr. was destroyed by flood waters, but he continued to farm adjacent land. Monies due him under his contract for the erection of mills were unpaid, so that Major Joshua Pilcher, Superintendent of Indian Affairs, St. Louis, wrote Crawford on 
September 19, 1839, asking what should be done. Crawford replied on November 17, saying he would attempt to seek an opinion from the Attorney General. Nevertheless, the matter dragged on. On January 26, 1841, Smith, Sr., writing from Burlington, complained to Augustus C. Dodge. He and Major Samuel Smith had not been paid some $\$ 600.00$ for tools, materials, and labor for work on the Soap Creek mill. He thought that Street had not forwarded the claim to the Indian Department before his death. Smith, Sr. also informed Dodge that he had not been paid for keeping Sac and Fox horses during the summer of 1840 when the Indians were at Prairie du Chien to make a treaty with the Winnebago tribe. ${ }^{30}$

Smith, Sr. insisted that his charge of $\$ 80.00$ for keeping the horses was not excessive even though General Henry Atkinson, who approved the idea, grumbled at the charge, saying Indian mounts live on grass. Smith, Sr. replied tartly that while horses did survive on grass in the country, they needed more in cities and densely populated counties. He hoped Crawford, to whom Atkinson referred his claim, "was better acquainted with the growth of vegetation in the City of Burlington," where he cared for the horses. ${ }^{31}$

One reason that Smith, Sr. so frequently prodded the government was the fact that John Beach, who succeeded Street as Indian Agent, removed him as a government miller in September 1840. Smith, Sr. never forgave Beach for that. When Smith, Sr. bid $\$ 1300.00$ to repair the Soap Creek mill, Beach did not accept the bid. Smith, Sr. also claimed that, after he was discharged as miller, Crawford promised to reinstate him. Governor John Chambers was forced to ask Crawford if that was true. ${ }^{32}$

Beach defended the removal of Smith, Sr., charging that he neglected his duties, absented himself from the mill without permission, and traded with the Sac and Fox without a license. Beach wrote Crawford that William Phelps, representative of Pierre Chouteau, Jr. and Company, St. Louis traders, was willing to certify that Smith, Sr. "about September, 1840, when the Indians were assembled for payment, requested me to take and enter into my accounts, certain of his against said Indians 
alleging as his reason that having no right to trade, he was unwilling to present any accounts in his own name." Phelps said he refused. He also accused Smith, Sr. of selling horses to the Sac and Fox.

Beach was equally blunt, informing Crawford that Smith, Sr. was a person of notoriously intemperate habits who furnished liquor to the Indians. He said that in February 1840 he forwarded to Lucas two affidavits proving that Smith, Sr. did traffic in liquor. Apparently Lucas did not investigate. Beach disliked Lucas about as much as Smith, Sr. disliked Beach. "As I have no ground whereupon to ask courtesy at the hands of Gov. Lucas, or any wish to desire of him even civility," Beach told Crawford, "I make no complaint of a continual course of conduct on his part, which would by other superintendents be deemed at least unusual interference with the legitimate duties of the Agent." ${ }^{33}$

It was not long before Lucas and Smith, Sr. struck back at Beach. Lucas wrote Crawford early in 1841 that he held a petition signed by 300 Indians addressed to the President of the United States. The Sac and Fox complained of the way Beach treated them and requested that Smith, Sr. replace him as agent. "The man they have recommended," said Lucas, "is well known to them, and as far as I have ever heard, has the confidence of both parties of the nation. And from my present acquaintance with him I have no hesitancy in saying that should he be appointed that he will use his best endeavours to promote peace and harmony among the Indians, to protect their interests against fraud." Lucas said he would be pleased if the wishes of the Indians were granted. ${ }^{34}$

It is possible that Lucas' defense of Smith, Sr. and his endorsement of the petition of the Sac and Fox so irritated Beach that he continued his dilatory practice of sitting on the claim of Smith, Sr. and not forwarding it to Crawford for action. Beach's Fabian tactics were based on the argument that the accounts of Smith, Sr. were unsupported by proper vouchers and could not be satisfied without such evidence. It may be that Beach honestly believed that Smith, Sr. was irresponsible and even guilty of malfeasance in office. However, Smith, Sr. insisted he rendered proper accounting in December 1842. ${ }^{35}$ 
Determined to bypass Beach, Smith, Sr. twice journeyed from his residence near Locust Grove, Jefferson County, to the nation's capital to plead his cause before Crawford. On his first trip in August 1842, Crawford was unavailable for an interview, but Smith, Sr. left a message. He would be willing, he said, to serve as miller at the Sac and Fox mills without compensation "other than the use of the mills when they are not required for grinding for the Indians." In March 1843, he again was in Washington City and spoke with Crawford. After Smith, Sr. left, Crawford got off a letter to Beach, telling him that Smith, Sr. said he had delivered to Beach an account of work done on the Sac and Fox mills "for the purpose of being forwarded to the Department." Crawford had not received it and requested Beach, if he had it, to transmit it without delay. ${ }^{36}$

Smith, Sr. had been annoyed with Crawford long before he conferred with him in March 1843. In September 1842, he wrote Crawford complaining of nonpayment. Once again, Crawford told him that all accounts growing out of transactions with Indian agencies must be examined and approved by agents before payment was authorized. When Smith, Sr. suggested he serve as miller when mills were not grinding for Indians, Crawford rejected the proposal. Such a plan might do great injury to the Sac and Fox. Although there might be honorable exceptions, "it would open a door where peculation \& fraud, without any means of detection, might be practiced."

Smith, Sr. did not help his cause when, in 1842, he "took a party of Indians to exhibit through the country." Beach said "they went off in a very clandestine manner, and are represented as being made up of the most wretched of the tribe." That was the way Governor Chambers quoted Beach in a letter to Crawford. Chambers said that Beach "fears that having made all he can by exhibiting, Smith, [Sr.] will leave them to find their way home without assistance. It is to be regretted that there is no punishment prescribed by law for such unfeeling speculations upon the ignorance and folly of the Indians." 38

It is understandable that Smith, Sr., when he talked with Crawford on March 28, 1843, was resentful and frustrated. Claims which he felt justified were tossed like a ball from one government department to another. Beach blocked payment on 
what Smith, Sr. believed flimsy and malicious pretenses. Crawford would not permit him to use grist mills even when they were idle and not grinding for the Sac and Fox. When he tried to aid the Indians by taking them on tour, his only reward was scathing criticism. His troubles were innumerable, and justice had forsaken him. He rationalized each and every one of a litany of grievances. So, in addition to seeing Crawford on March 28, Smith, Sr. cast aside caution and prudence and acted in a manner which not only placed him in conflict with Smith, Jr., but also made him a fugitive from the law.

\section{Smith, Jr. v. Smith, Sr.}

When the Treaty of October 11, 1842 was negotiated, provision was made for the payment of debts owed to legitimate traders by the Sac and Fox. Smith, Jr. submitted a bill in the amount of $\$ 6,603.82$, but was allowed only $\$ 4000.00$. Although disappointed, he made no protest, believing payment would come in good time, and anticipated no difficulties. Unfortunately, he was mistaken, little thinking that monies due him would be snatched by an imposter using his name. ${ }^{39}$

Although Smith, Jr. knew the government moved slowly and payment of his $\$ 4000.00$ would not arrive quickly, he began to fret after the winter months of 1842 were torn from the calendar. Then followed the first three months of 1843 . When no government draft reached him by April 14, he wrote Crawford inquiring about the delay. After all, it was some seven months since the claim was approved and payment authorized. Early in May Crawford wrote him that his inquiry had been referred to the Treasury Department. There was nothing Smith, Jr. could do but wait. ${ }^{40}$

On May 28 the blow fell. That day the mail brought Smith, Jr. a letter from John Eakin of the Second Auditor's Office, United States Treasury. Eakin wrote that about March 28 a Smith, Jr., or a person representing himself as such, appeared in Washington City, claimed, and was paid the $\$ 4000.00 .{ }^{41}$

The disconcerting and entirely unexpected news sparked a spate of letters. Smith, Jr., bypassing Eakin sent off a reply to the Second Auditor, William B. Lewis. 
I am the only licensed trader of the name of Jeremiah Smith in the Territory of lowa or ever has been who was a trader with the Sac \& Fox Indians. I have neither disposed of my claim against the Government nor authorized any person, or persons to receive my money, or receipt for the same. The Jeremiah Smith who has received money lately as I understand at Washington, had a claim against the Sac \& Fox Indians, which was not allowed him by his long absence at the time of the Treaty and some other informality of his papers, according to the instructions of the offices of the Indian department, and his excellency Gov. John Chambers, the Commissioner of the Genl. Government.

Smith, Jr. requested that a draft in the amount of $\$ 4000.00$ be sent him quickly as "I am much necessitated for money." 42

Dodge penned an indignant protest to Lewis, telling him that a "base and shameful fraud" had been practiced upon the government and affirming that Smith, Jr. never was in Washington City and furthermore had not been out of Iowa Territory for years. Smith, Jr., he said, was well-known as a person of integrity. Then Dodge spoke of the individual who was presumed to have received the $\$ 4000.00$.

There is a Jeremiah Smith, Senior, who resides near Fairfield, in this Territory, who was at Washington City, about the time this money was drawn. This Mr. Smith had a claim for a few hundred dollars, which was not allowed, at the Treaty, and of course not included in the schedule of debts. Whether he was the person who drew the money, of course, I cannot say.

Dodge emphatically informed Lewis that Smith, Jr. was in the utmost need of money and was in imminent danger of losing some of his most valuable real estate if he were not paid. ${ }^{43}$

Additional support also came from Arthur Bridgman, Burlington businessman and one of the commissioners at the Treaty of 1842 , who urged Lewis to pay the claim through the office of Governor Chambers. Smith, Jr., on May 31, wrote Lewis that he had talked with Governor Chambers and told him he preferred that his claim be paid through his office as he believed Chambers to be an honest man, "which I think are not numerous in the present day." On June 25, Smith, Jr. sent Eakin a long 


\section{The Annals of Iowa}

communication. In it, Smith, Jr. said he had been in touch with Smith, Sr., who stated he had not received money due Smith, Jr. "He informs me," wrote Smith, Jr., "that he called at the [treasury] office on business, and the clerk enquired of him if his name was Jeremiah Smith, Senr.-he informed the clerk that it was-then the clerk informed him, his money was ready he does not say whether he received any money or not." Smith, Jr. went on to tell Eakin that he sent a gentleman from Burlington to talk with Smith, Sr. at his residence near Fairfield, but the envoy received little satisfaction. ${ }^{44}$

Smith, Jr. said he had nothing particular against Smith, Sr.

But think it averages with some of the officers of the government conduct at the present. [Smith, Sr.] has been at Washington City a considerable portion of last Congress and it appears to me is becoming quite Scientific in political matters-he is a Free Mason also which I am unable to say whether that would be any disqualification to his character or not, as they do their business in secret-Though my own opinion is that it is, this is all.

Finally, Smith, Jr. gave Eakin his explanation of why Smith, Sr. took the money which did not belong to him: He considered himself mistreated when he was a government miller and felt he was discriminated against when the government refused to approve a claim of $\$ 2500.00$ against the Sac and Fox. "My opinion," concluded Smith, Jr., "is that he has considered himself defrauded by the Govt. and being of the same name as myself, has taken this method to get his just dues, and in getting his just dues, he has received several hundred dollars, more than which was his dues." It is interesting to note that Smith, Jr. indicates a certain sympathy for Smith, Sr.

In August, Charles B. Penrose, Solicitor of the Treasury, wrote Smith, Jr., suggesting that he collect his money from "the Individual who has practised fraud on the government, or wait until the prosecuting attorney collects it of the Jeremiah Smith, Senr." That, Smith, Jr. replied to Penrose, was "a new mode of doing business." He had cooperated with the government in every possible manner. He could do nothing more. "I much need the money and if the officers of the government think that 
I am entitled to it, without previous investigation, please send it to me, as previously directed, if not I will lay the matter before Congress." 45

The refusal of Smith, Jr. to collect from Smith, Sr. and the threat of taking his case directly to Congress did not surprise Penrose and forced the government to bestir itself. There were relatively few options: The government could reimburse him in full and consider the money paid Smith, Sr. lost. It could attempt to regain the money from Smith, Sr. It could refuse to pay Smith, Jr. The one thing it could not do was to do nothing if only because of the persistent pressure exerted by Smith, Jr. and his supporters.

Penrose, not quite knowing what course was best, got in touch with J. G. Deshler, United States Attorney for Iowa, whose office was in Bloomington, later known as Muscatine. Penrose suggested that Deshler go to Fairfield and bring suit against Smith, Sr., for the latter returned there, from Washington City with the funds obtained fraudulently. Deshler learned that Smith, Sr. had no property and that "nothing could be made out of him." When in Burlington, Deshler called upon Smith, Jr. who told him that "Smith of Fairfield carried the money he received about his person and that he had refused to give it up-that he was worth nothing, and had went to the Indian Country." Chambers told Deshler that the Fairfield Smith had been intentionally guilty of swindling. When Bridgman was interviewed, he said that Smith, Sr. had called upon him to ask if any claim had been allowed him. Bridgman said no. Thus, Smith, Sr. left with full knowledge that nothing was allowed him. "My own opinion," Deshler wrote Penrose, "is from what I have learnt of this transaction, that to take him, said Smith, by a requisition from the President for swindling, and take him back to the District, the greater part of the money might be recovered, but in case such a course is not pursued the Government must meet with a loss to the whole amount." Deshler also said that Chambers told him that Smith, Jr. was much in want of the money due him, and "was suffering in a pecuniary way very much because of its detention." 46 
the proper handling of the matter was a delicate affair. No federal agency wished to do anything but keep its bureaucratic skirts clean and, if possible, not to admit to carelessness in paying the wrong individual the right amount. Crawford, for example, hastened to forward to James M. Porter, Secretary of War, a resume of the incident, stating that "In the Indian office the paper [authorizing payment] was properly prepared, and not only so but a special order was given to be particularly careful so as to prepare it, and the reason given for such order was that the Commissioner [of Indian Affairs] did not know whether the applicant was the rightful claimant or not." 47

Porter, in turn, forwarded Crawford's letter with a note of transmittal to President Tyler, informing the President that "By the facts ascertained it appears that the requisition was drawn in favor of the proper person 'Jeremiah Smith Junior,' and if the account was paid to the wrong person, the error [occurred] at the Treasury where the money was paid." 48

Dodge never doubted but that a Treasury Department clerk was duped by Smith, Sr., but the erring minor official was the agent of the Department and therefore that branch of the government must assume responsibility. He continued to urge payment in full to Smith, Jr. Early in December, he posted a firm communication to John C. Spencer, Secretary of the Treasury. "In this State of the case," Dodge said, "I wish to know whether Mr. Smith's money will be paid him or not-and if not what course your department will determine upon in regard to the matter." Spencer turned Dodge's blunt question over to Penrose, requesting information. Penrose informed him that the government was attempting to collect from Smith, Sr., but had met with little success. He thought it could be proven that when Smith, Sr. was asked by the clerk if he were Smith, Jr., he replied "substantially that the Jr. was of no consequence or a mistake, leading them to the conclusion that he was the veritable claimant." 49

Meanwhile, Smith, Jr., about forty-one years old, with a large family and in financial straits, sat in Burlington growing more and more impatient. All he wanted was to be paid. He could not understand why federal red tape could so snarl itself 
as to prevent settlement of a just claim. His only recourse was to continue to badger those in Washington City with power to settle the matter. So, on February 1, 1844, he wrote Spencer.

Being very desirous to know what disposition has been made of my claim, made under the Sac \& Fox Treaty of 1842 under the Superintendance of his Excellency Gov. John Chambers of Iowa Territory. Some Considerable time has elapsed since I have herd from you on the Subject and as Congress has been Conviened Some time I presume you will be able to give me some definite answer in regard to what disposition has been made of the Claim if any, and if not whether their will be any further action on the subject or not by Congress.

Although his sentence structure and spelling left something to be desired, the letter clearly reflects the writer's anxiety.

Spencer, about as weary of the drawn-out controversy as Dodge and Smith, Jr., made his decision. The Treasury Department, he wrote Dodge, would pay Smith, Jr. the full amount owed him, but in order for the claimant to receive the money it would be necessary for him to appear personally in Washington City and be identified. That stipulation infuriated Smith, Jr. He told Spencer he would travel to the capital only if he could not receive his money in any other manner. He preferred that the funds be sent him through Governor Chambers' office. With considerable ire, he told Spencer what he thought.

I have done considerable business in my life time, both with the Government and Individuals but never have had any thing to equal this for procrastination, you had better send this money to me if I have to come to Washington City, I Shall endevour to make you pay for the building I had while in possession of the Government if there is any Justice to be had at your City under this administration for me.

He was referring, of course, to the fact that he was never reimbursed for his loss when the capitol burned in Burlington. ${ }^{50}$

With the assistance of Chambers and Dodge, Smith, Jr. devised a plan which permitted him to remain in Burlington and still receive the $\$ 4000.00$ due him. He gave Dodge power of attorney. Armed with that, Dodge was paid the proper amount and forwarded it to its owner. ${ }^{51}$ 
Spencer's settlement with Smith, Jr. ended one problem, but another remained. That concerned the apprehension and, if possible, the bringing to trial of Smith, Sr. All knowledgeable persons were certain that he was the culprit who absconded with money which rightfully belonged to Smith, Jr.

Penrose took action against Smith, Sr. during January 1844 when he requested Deshler, United States Attorney for Iowa, to proceed. Deshler, who resided in Bloomington, directed Isaac Leffler, United States Marshal in Burlington, to secure a warrant, arrest Smith, Sr., and bring him to trial. Charles Mason, Chief Justice of the Iowa Supreme Court, issued the warrant, and Leffler dispatched a deputy marshal to ride to the farm of Smith, Sr. near Fairfield, a distance of about a hundred miles. There Smith, Sr. was seized and returned to Burlington. ${ }^{52}$

The prisoner was brought before Mason for a hearing lasting two days. Deshler was unable to attend because "our whole country was flooded," but Lacon D. Stockton, who a year later successfully prosecuted the Hodge brothers for murder, stood in for him. The case was dismissed on a technicality, and the accused walked out of court a free man. ${ }^{53}$

Marshal Leffler refused to let the matter drop. He quickly asked for and received a bench warrant, put it into the hands of a deputy, and ordered him to serve it. Taking three men with him, the deputy left Burlington at daylight on February 1. They rode forty miles in six days and returned empty-handed. Smith, Sr. had eluded them only because friends, learning of the warrant, sent a runner to alert him in time for him to slip away. ${ }^{54}$

A frustrated Leffler returned the warrant as required. Deshler then obtained a third warrant, gave it to Leffler, and, once again, the hunt was on. Leffler, in turn, passed the paper to a dragoon captain named Irish, "a very competent man." He directed Irish to trail Smith, Sr. for as long as there were prospects of collaring him. For twenty days the dragoon officer, with two men, scoured the western country "near the Indian Boundary line." Leffler held little hope that Irish would be successful and admitted that the captain's chances were slight. The fugitive, Leffler wrote Penrose, "has plenty of money, has bought I am told one of the best kind of horses, he is acquainted 
with nearly all the Indians, speaks their languages, and has a great many friends among the whites, who give him notice." The property of Smith, Sr. had been taken for his debts, and it was rumored that he intended to go to Oregon or Texas. Leffler made no bones of the fact that if Irish failed there was little hope of capturing the runaway, although, Leffler continued, he heard that some of the unprincipled friends of the hunted man would, if paid a hundred dollars, run him down and hang him. ${ }^{55}$

Leffler's prediction was correct. Irish's mission failed. The cunning dodger eluded attempts to net him, sneaking from the Indian country-if, indeed, he ever was there-to seek sanctuary in Illinois. In the Sucker State, he was apprehended by Dr. L. H. Hicock (sometimes spelled Hickok) whom Governor Chambers said left a lucrative Burlington practice to trail him, although why the doctor did so is difficult to understand. Smith, Sr. was taken to court and released, an action which Chambers thought "a very extraordinary discharge." 56

Upon release, Smith, Sr., said Chambers, "took refuge in Nauvoo (now becoming the City of refuge for many scoundrels), where he was forced by Mr. Johnson, ex-Marshall of this territory." Johnson failed to bring the accused to justice. By then Smith, Jr. had lost interest. ${ }^{57}$

More and more, during the late 1840s, the fortunes of Smith, Jr. steadily declined and his health deteriorated. He lost the political power he once held. He managed his financial affairs ineptly. He seems to have spent more time at home working his land. On February 28, 1852, at age fifty, he died in his Burlington residence and was buried in Aspen Grove Cemetery. ${ }^{58}$

One who knew him well said that whisky finally gained the victory over him. His obituary characterized him as an honest and good man and a useful citizen known for many acts of charity and for his liberality. "Like other men he had his faults, but we verily believe he had no enemies." No mention was made of his early career except to say he arrived in Burlington in 1834, which, of course, was an error. ${ }^{59}$ Ellen, his wife, and eight children living at home survived him. ${ }^{60}$ 


\section{The Annals of Iowa}

Although Smith, Jr. left no last will and testament, an inventory was taken of his goods, chattels, and effects. The property was pathetically meager for an individual who once was reputed to be the wealthiest man in the county. The inventory listed a horse appraised at $\$ 80.00$, and another at $\$ 67.00$. Seven head of cattle were worth $\$ 76.00$. A corn sheller was valued at ninety cents, and a gun at two dollars. Items inventoried, but assigned no value, were a bureau, wardrobe, "cubbard ware \&c.," two dining tables, five "bedstids" and bedding, a cooking stove, furniture, two sets of chairs, and two stands. There were also notes on various persons in the amount of $\$ 759.00$, most of them believed to be worthless. That was all. ${ }^{61}$

\section{Notes}

${ }^{1}$ Unless otherwise indicated, sources cited, particularly letters, are photocopies from the National Archives. They are so designated. Microfilm materials are cited in full. W. O. Weaver, Wapello, Iowa, February 17, 1976, to Jordan; John Porter Bloom, National Archives, February 3, 1976, to Jordan; Smith, Jr., Burlington, June 25, 1843, to John Eakin, 2nd. Auditor's Office, Washington City.

${ }^{2}$ The Jeremiah Smiths-Senior and Junior-were not the only individuals whose names made identification difficult. In Nauvoo, Illinois, for example, Joseph Smith, Sr. and Joseph Smith, Jr. were mistaken one for the other. Hyrum Smith testified in court that the defendant was his brother, and "that his name is not Joseph Smith Junior, but his name is Joseph Smith Senior, and has been for more than two years past." Lee County Democrat (Fort Madison), July 29, 1843.

${ }^{3}$ Thomas H. Smith, Ohio Historical Society, Columbus, May 19, 1976 to Jordan; History of Franklin and Pickaway Counties (n.p.: Williams Bros., 1880), 276; Alice E. Smith, The History of Wisconsin (Madison: State Historical Society of Wisconsin, 1973), 236; Wisconsin Historical Society, Sixty-Eighth Annual Meeting, Proceedings (Madison: Wisconsin Historical Society, 1920), 153-54; The Palimpsest (July 1947), 223-24. Only one Jeremiah Smith was mentioned in the history of Franklin and Pickaway counties and in tax rolls.

"For the Jeremiah Smith of Greene County, again the only one mentioned, see History of Greene and Jersey Counties, Illinois (Springfield: Continental Historical Company, 1885), 587, 649, 1063, 1084.

${ }^{5}$ For sketch of Fry, see History of Greene and Jersey Counties, 702-04.

'Frank E. Stevens, The Black Hawk War (Chicago: Frank H. Stevens, 1903), 194, 124-25, 214-15; Ellen M. Whitney, ed., The Black Hawk War, 1831-1832 (Springfield: Illinois State Historical Library, 1960), passim, but especially 155-57, 416n; Cecil Eby, "That Disgraceful Affair," The Black 
Hawk War (New York: W. W. Norton \& Company, 1973), 211. For Smith, Sr. addressed as "Colonel," see Burlington Hawk-Eye and Iowa Patriot, April $18,1841$.

${ }^{7}$ Western Historical Company, The History of Des Moines County, Iowa (Chicago: Western Historical Company, 1879), on p. 475 repeats verbatim the statement in The Burlington Patriot quoted above; on p. 477, it states that Smith, Jr. brought merchandise to the town in 1833, "but previous to that, he had taken up a claim about a mile and a half back [west] from the river, and made some valuable improvements on it." On p. 471, an old settler is quoted, saying that in September 1833, Jeremiah Smith, Jr. located on the prairie west of town and that he "caused us to lay off some lots, as he said he would purchase a lot if we would sell it to him. If we would not do that, he should occupy the ground anyway, as he had come to start in trade. If he could not do it peaceably, he would forcibly. It was not our intention to lay off a town until we had acquired title, but the positive stand taken by Smith caused us to change our minds."

${ }^{8}$ William Salter, ed., "Old Letters," Annals of Iowa (July 1908), 434, where he writes that the original cabin in 1908 still stood at 2700 West Avenue, the property then being within the city limits. For an account of Amelia Smith Hay and early life, see obituary in Burlington Hawk-Eye and Burlington Gazette, October 10, 1918. See also Uriah Biggs, "Sketches of the Sac and Fox Indians, and the Early Settlement of Wapello County," Annals of Iowa (July 1865), 487: "My first and only interview with this noted chief [Black Hawk] was at Rock Island, at the time of the treaty for the Iowa Reserve in 1836, about one year before his death. I was introduced to him by his intimate acquaintance and apologist, the late Jeremiah Smith, [Jr.] of Burlington. . . . Mr. Smith, unfortunately for the repose of Black Hawk's feelings and unconscious of its effect, mentioned the writer of this sketch as a surveyor of public lands, a character always unwelcome among Indians. This remark I much regretted, as Black Hawk's countenance was instantly covered with gloom, and he rather petulantly said: 'The Sho-mo-ko-man was strong and would force the Indians to give up all their lands.'" For Dr. Potts, see History of Greene and Jersey Counties, 723.

'The warehouse store was situated on Lot 651 , Old City. Iowa State Historical Department, Division of Historical Museum and Archives, Des Moines, Jeremiah Smith, [Jr.] Account Books, 1836-37, Ledger, 1836-38, Account Book, 1836-38. Hereafter cited as ISHDMA. Smith, Jr. was no accomplished bookkeeper, so that his entries leave something to be desired. Philip D. Jordan, "Moses Dillon Jordan," The Palimpsest (July 1949), 209-36.

${ }^{10}$ Henry Shaw, St. Louis, August 23, 1836 to Smith, [Jr.], receipt for merchandise in amount of $\$ 98.00$. Jeremiah Smith, [Jr.] Collection, Special Collections, University Libraries, University of Iowa. Hereafter cited as SPULUI.

${ }^{11}$ Robert Lucas, Burlington, August 12, 1839 to T. Hartly Crawford, Commissioner of Indian Affairs; Lucas, Burlington, July 5, 1839, To Whom It May Concern, stating that Jeremiah Smith, [Jr. ] was issued a trader's license on 


\section{The Annals of Iowa}

that date, ISHDMA. If there was a license prior to 1839 , it is unknown to this author.

${ }^{12}$ Smith, Jr. Account Book, 1836-40, SPULUI. The sales were proven by Samuel I. [J?] Parker and Isaac Frer.

${ }^{13}$ Clarence E. Carter, ed., Territorial Papers of the United States (Michigan), 12: 1125; Charles J. Kappler, ed., Indian Affairs, Laws and Treaties, 5v. (Washington: GPO, 1903-41), 2:352-53; Arthur Springer, History of Louisa County, 2v. (Chicago: S. J. Clarke Publishing Company, 1912), 1:68. For the squabble over location of the capital, see Alice E. Smith, James Duane Doty: Frontier Pioneer (Madison: State Historical Society of Wisconsin, 1954), 192208. For Doty, see Dictionary of American Biography, 5: 390-91, hereafter cited as DAB. Hawk-Eye and lowa Patriot, June 25, 1840: "Major Smith made a few remarks at a Van Buren Convention held in Burlington on Saturday last."

${ }^{14}$ Wisconsin Territorial Gazette and Burlington Advertiser, October 12, 16, 1837; Burlington Patriot, December 13, 1838. For a brief history of Old Zion, see First Methodist Church Successor to Old Zion, 1834-1954 (Burlington: First Methodist Church, 1964).

${ }^{15}$ Wisconsin Territorial Gazette and Burlington Advertiser, December 23 , 30, 1837, January 13, 1838; Iowa Territorial Gazette and Burlington Advertiser, November 16, 1839; Benjamin F. Shambaugh, ed., Executive Journal of Iowa, 1838-1841 (Iowa City: State Historical Society of Iowa, 1906), 289, 300; Burlington Hawkeye and Iowa Patriot, November 19, 1840; Louis Pelzer, Augustus Caesar Dodge (Iowa City: State Historical Society of Iowa, 1908), 96; Hawkins Taylor, "Before and After the Territorial Organization of Iowa," Annals of Iowa (January 1861), 452-53.

${ }^{16} \mathrm{~W}$. B. Slaughter, Mineral Point, February 20, 1838 to Smith, Jr.; Slaughter to Jones, February 20, 1838, ISHDMA.

${ }^{17}$ House Doc., Rep. No. 148, 28 cong., 2 sess., February 15, 1845 re: Jeremiah Smith, Jr.; Henry May, Washington City, July 25, 1844 to Smith, Jr.; Henry W. Starr, Burlington, October 5, 1844 to Smith, Jr.; James Connelly, Burlington, October 7, 1844 to Andrew Stewart, ISHDMA.

${ }^{18}$ House Doc., Rep. No. 148, February 15, 1845; May to Smith, Jr., March 10, 1845 .

${ }^{19}$ John Porter Bloom, ed., Territorial Papers of the United States (Wisconsin), 27: 9-13; Pelzer, Augustus Caesar Dodge, 50-61; Pelzer, Henry Dodge (Iowa City: State Historical Society of Iowa, 1911), 71; Cyrenus Cole, A History of the People of Iowa (Cedar Rapids: Torch Press, 1921), 150-52; Fort Madison Patriot, July 11, 1838. The possibility that Smith, Jr. might be named register of the Burlington land office was no idle dream, for on December 18, 1836 Henry Dodge wrote George W. Jones saying he was enclosing recommendations for "Major Smith and Mr. Chance for two of the Land Offices west of the Mississippi should they be created. . . . Land offices are now considered fortunes and are sought after with great avidity." David R. Chance was a member of the Wisconsin Territorial Legislature in October 1836 and 
Smith, Jr. was a member of the Council. Both were interested in securing the appointment of Hiram C. Bennett, a Burlington resident, as United States Marshal, but he did not receive the office. For Dodge's letter to Jones, see William Salter, ed., "Letters of Henry Dodge to Gen. George W. Jones," Annals of Iowa (April-July 1898), 389-90; for Smith and Chance, see Bloom, ed., Territorial Papers (Wisconsin), 27: 88, 89, 879-80.

${ }^{20}$ Purchase and survey of Burlington lots drawn from bill for payment by Charles Handelers, engineer and surveyor, who after the death of Smith, Jr. in 1852 , claimed $\$ 13.00$, Smith, Jr. Estate Papers, Clerk of District Court, Burlington, Des Moines County, Iowa. William O. Weaver, Hail to the Chief: True Tales of Old Wapello (Wapello: Louisa Publishing Co., Ltd., 1974), 15, where Weaver writes that neither he nor the General Land Office were able to find the original or a copy of the plat to which Smith, Jr. referred. Weaver, June 19, 1974, to Jordan in which the former writes that the National Archives searched, but did not find the plat. Weaver furnished Jordan copies of the transfer of properties of August 27, December 24, 1844. See Springer, History of Louisa County, 347: "Full payment was made January 1, 1846 on Lots numbered one and two, and the Southwest Quarter of the Northwest Quarter of Section Thirty-five, in Township seventy-four North of Range three, West in the District of Lands subject to sail at Fairfield, Iowa Territory, containing one hundred and forty acres, and ten hundredths of an acre."

${ }^{21}$ Iowa Patriot, June 6, 1839.

${ }^{22}$ Clerk's Office, Burlington City Council Minutes, June 15, 1841; M. Riter's Field Notes and Plat of Survey of Burlington Graveyard, June, 1841, ISHDMA; Burlington Hawk-Eye, February 1, 1849; Clara M. Turner, Cassville, Wisconsin, February 26, 1972 to Martha Jordan Soland; A. M. Antrobus, History of Des Moines County, 2v. (Chicago: S. J. Clarke Publishing Company, 1915), 1: 106. The Smith Cemetery occupied ground upon which Burlington University and the Burlington High School later were located.

${ }^{23}$ For Brown's recollections, see Burlington Hawk-Eye, January 1, 1887; for execution of the Hodges, see Charles Negus, "The Early History of Iowa," Annals of Iowa (October 1870), 303-04; Burlington Hawk-Eye, June 5, 12, 19 , 26, 1845; Burlington Gazette, June 28, July 12, 1845; Saturday Evening Post (Burlington), March 27, 1886; also Philip D. Jordan's introduction to Edward Bonney, The Banditti of the Prairies (Norman: University of Oklahoma Press, 1963). A typical account is in Antrobus, Des Moines County, v. 1, chap. 14. For years an unverified rumor had it that Smith, Jr. was among those who objected to burying the Hodges in the Smith Cemetery.

${ }^{24}$ Turner to Soland, February 26, 1972; Burlington Hawk-Eye, July 28, 1868; Burlington Daily Telegraph, April 23, 1853, Antrobus, Des Moines County, 1: 106.

${ }^{25}$ See notice in Iowa Territorial Gazette and Burlington Advertiser, December 8,1838 , when Smith, Jr. offers for sale "one of the most valuable lots" in Burlington. On January 21, 1841, the Burlington Hawkeye and Iowa Patriot reported that on January 10, ruffians in Augusta, Iowa, entered the stable of 


\section{The Annals of Iowa}

Levi Moffett and mutilated "in most shocking manner" a span of elegant gray horses belonging to Jeremiah Smith, Jr., who was in Augusta to pick up a load of flour at the mill and haul it to Nauvoo, Illinois.

${ }^{26}$ See footnote 1, Smith, Jr., June 25, 1843 to Eakin.

${ }^{27}$ Street served as Indian Agent from 1837 until his death in 1840. See William B. Street, "General Joseph M. Street," Annals of Iowa (July-October 1895), 81-105; $D A B, 18: 136-37$. Details of the life of Smith, Sr. are scant and contradictory. Antrobus, History of Des Moines County, 1: 72 cites the first census of the Original County of Demoine, Iowa, July 1836: "Jeremiah Smith, Sr. 7 males under age 21 in family; 2 males over 21 in family; 2 females under 21 in family; 1 female over 21 -a total of 12 in family." Springer, History of Louisa County, 1: 52 cites the same source. Antrobus, on p. 85, states that Jeremiah Smith, Sr. came to Burlington in 1833 . That can only mean, as indicated in the census of 1836, that Smith, Jr., when he arrived in 1833, brought his father with him and that the latter was known as Jeremiah Smith, Sr. In the Federal Census of 1840, it is recorded that in the family of Smith, Sr. there was a male between the ages of sixty and seventy and a male between the ages of thirty and forty. The latter, Smith, Jr., was born in 1802 and hence would have been about age thirty-eight in 1840. The elder Jeremiah Smith (father of Jeremiah Smith, Jr.) is not listed in the Federal Census of 1850 and it is reasonable to presume he died in the decade between 1840 and 1850 . The 1850 census did list a Jeremiah Smith, age forty-five, which, reckoning year, month, and day, showed the year of birth as 1802 . He-Smith, Jr.-is the individual whose career is examined in this article. His father, Smith, Sr., is not to be confused with the Jeremiah Smith, Sr. who contracted with Street to build government mills. Furthermore, letters which the Wisconsin Territorial Gazette and Burlington Advertiser of July 20, 1837 and October 6, 20, 1838 advertised as held in the post office until called for and addressed to Jeremiah Smith, Sr. or to Jeremiah Smith belonged to the above mentioned Smiths and not to the Jeremiah Smith, Sr. who contracted to construct mills.

${ }^{28}$ Photocopy of Articles of Agreement Between Joseph M. Street, United States Indian Agent, of the one part, and Jeremiah Smith, Senior, of Des Moines County Wisconsin Territory, on the other part, Burlington, June 1, 1838. When Smith signed, he omitted the "Senior." See Negus, "The Early History of Iowa," Annals of Iowa (January 1870), 13; Jacob Van der Zee, "The Opening of the Des Moines Valley to Settlement," Iowa Journal of History and Politics (October 1916), 502, 503.

${ }^{29}$ See footnote 11. Photocopy, Bond of Joseph M. Street As Indian Agent for the Sac and Fox, May 6, 1839; Crawford to Lucas, September 19, 1839.

${ }^{30}$ Photocopy, Crawford, February 7, 1839 to Pilcher, NA, M574,R2, Special File 15, Office of Indian Affairs, 1807-1904, "Samuel and Jeremiah Smith, [Sr.] Claim for Labor at the Sac and Fox Mills in 1840." Hereafter cited as File 15.

${ }^{31}$ File 15. Photocopy, Smith, Sr., Burlington, January 26, 1841, to Dodge; Atkinson, Jefferson Barracks, January 2, 1841, to Smith Bros. \& Co., St. Louis: "Your letter of the 12th covering an account of Jeremiah Smith [Sr.] of 


\section{Iowa's Puzzling Jeremiah Smiths}

Iowa Territory to the amount of $\$ 80$ for keeping horses of the Sac and Fox Indians whilst a deputation of those Indians were absent on a visit to Prairie du Chien for the purpose of holding a treaty with the Winnebagoes. The charge is an unusual one, as Indian horses live on grass at home and abroadstill if the account was of the character sanctioned by the usages of the service there is no public monies subject to my orders that I can direct to be applied to the liquidation of the claim. I would advise that you return the accounts to Mr. Jeremiah Smith and that he should forward them to the Hon. Aug. Dodge at Washington to be submitted to H. Crawford, Esq., Superintendent of Indian Affairs for his action and Instructions."

${ }^{32}$ File 15. Photocopy, Smith, Sr., Burlington, June 13, 1841, to Crawford; Beach, Sac and Fox Agency, December 31, 1840, to Crawford; Chambers, Burlington, June 9, 1841, to Crawford. On September 2, 1842, Smith, Sr. wrote Crawford: "As I do not wish to have any intercourse whether on business or otherwise with $\mathrm{Mr}$. Beach if it is possible to avoid it, I would respectfully enquire of you if the privelege of transmitting my account duly authenticated and proved to your department without his intervention can be granted me."

${ }^{33}$ Photocopy, Beach, Sac and Fox Agency, October 30, 1840, to Crawford.

${ }^{34}$ Photocopy, Lucas, Burlington, February 18, 1841, to Crawford.

${ }^{35}$ Photocopy, Crawford, March 28, 1843, to Beach.

${ }^{36} \mathrm{Ibid}$. File 15. Smith, Sr., Washington City, August 4, 1842, to Crawford.

${ }^{37}$ Photocopy, Crawford, September 27, 1842, to Smith, Sr.

${ }^{38}$ Photocopy, Chambers, Burlington, July 23, 1842, to Crawford. John C. Parish, John Chambers (Iowa City: State Historical Society of Iowa, 1909), 179: "During the summer of 1842 the Indian border line was a scene of turbulence. The Indians were restless; whites expelled from the red men's country were vindictive. The whiskey sellers were active and their increasing numbers contained many desperadoes of the most dangerous type. An old trading house, abandoned by Pierre Chouteau, Jr. and Company was burned to the ground. The Agent and the Superintendent of Indian Affairs were shot in effigy, and one Smith, a troublesome fellow who had been christened Jeremiah by his unprophetic parents, gathered a band of Indians and clandestinely took them off to exhibit through the country." For an account of the burning of the Chouteau, Jr. and Company trading house, see Hawk-Eye and Iowa Patriot, April 8, 1841 in response to story in Burlington Gazette, February 13, 1841. Parish gives the time of the fire as during the summer of 1842 , but others place it on the night of February 23, 1841.

${ }^{39}$ For the treaty and the claim of Smith, Jr., see Kappler, Indian Affairs, 2: 404-07; Benjamin F. Shambaugh, ed., Messages and Proclamations of the Governors of Iowa, 6v. (Iowa City: State Historical Society of Iowa, 1903-04), 1:262, for John Chambers Second Annual Message, December 7, 1842; Alfred Hebard, "An Indian Treaty and Its Negotiation," Annals of Iowa (April 1894), 397-408. ISHDMA holds a small broadside, about 6 by 9 inches, entitled Schedule of debts due from the confederated tribes of the Sac and Fox Indians, to be paid by the United States, under the provisions made and con- 


\section{The Annals of Iowa}

cluded at the Sac and Fox agency, in the Territory of Iowa, on the eleventh day of October, in the year to which this schedule is annexed as a part thereof. Line 20 reads: "Jeremiah Smith, Jr., licen'd trader, Burlington, Iowa, \$4000." Smith, Sr. was not listed. See also Parish, John Chambers, 181-84.

${ }^{40}$ Photocopy, Crawford, May 10, 1843, to Smith, Jr.

${ }^{41}$ Photocopy, Eakin, April 11, 1843, to Smith, Jr.

${ }^{42}$ Photocopy, Smith, Jr., May 28, 1843, to Lewis.

${ }^{43}$ Photocopy, Dodge, May 29, 1843, to Lewis.

${ }^{44}$ Photocopy, Bridgman, May 30, 1843, to Lewis; Smith, Jr., June 25, 1843, to Eakin.

${ }^{45}$ Photocopy, Penrose, August 19, 1843, to Smith, Jr.; Smith, Jr., September 10,1843 , to Penrose.

${ }^{46}$ Photocopy, Deshler, September 24, 1842, to Penrose.

${ }^{47}$ Photocopy, Crawford, October 21, 1843, to Porter.

${ }^{48}$ Photocopy, Porter, October 23, 1843, to the President. Crawford continued to insist that no one connected with the Indian Office or the War Department deserved the slightest censure and that if anyone wanted information he should ask the Treasury Department.

${ }^{49}$ Photocopy, Dodge, December 11, 1843, to Spencer; Penrose, December 14,1843 , to Spencer.

${ }^{\text {so }}$ Photocopy, Spencer, January 27, 1844, to Dodge; Smith, Jr., February 21, 1844 , to Spencer.

${ }^{51}$ Photocopy, Smith, Jr., February 25, 1844, to Dodge; Dodge, March 9, 1844, to Secretary of the Treasury; power of attorney dated February 21, 1844.

${ }^{52}$ Leffler, a Burlington attorney, received a recess appointment as United States Marshal on March 25, 1843 and was confirmed by the Senate on January 16,1844 . He was removed on July 3,1845 . Leffler replaced Thomas B. Johnson, who later was among those who helped in the pursuit of Smith, Sr. In December 1842, Stephen Whicher, United States Attorney for Iowa, wrote Leffler: "The sureties of Thomas B. Johnson held a conference last night and united in writing a letter to the Secretary of the Treasury requesting him to withhold any further supply of funds until they can have an opportunity to examine his affairs as Marshal of Iowa. . . . This movement on our part will be a signal for his removal. The question of his removal was fully discussed and your appointment spoken of generally with approbation. . . . Permit me to suggest that you without delay address a line to the President and request the appointment of yourself." NA. M687, Roll 19, "Letters of Application and Recommendation During the Administrations of Martin Van Buren, William H. Harrison, and John Tyler, 1837-1845; also M687, Roll 7. Philip D. Jordan, "The U.S. Marshal on Iowa's Frontier," Palimpsest (March/April 1973), 141-42. For Mason, see DAB, 12: 357-58. Photocopy, Leffler, February 2, 1844 , to Penrose; Leffler, February 13, 1844, to Penrose.

${ }^{53}$ Photocopy, Deshler, December 18, 1844, to Penrose. For Stockton, see Antrobus, Des Moines County, 1: 401; Biographical Review of Des Moines County, Iowa (Chicago: Hobart Publishing Company, 1905), 1035. Smith, 
Sr., it was said, "employed the best talent in the territory" to represent him, but the names of his attorneys were not mentioned. As of this writing no records of the "Case of Jeremiah Smith, Sr." were found in the office of the Clerk of the District Court, Des Moines County, although it is possible that the documents, if extant, were misfiled and may yet be found.

${ }^{54}$ Photocopy, Leffler, February 29, 1844, to Penrose. Iowa Territorial Gazette and Burlington Advertiser, February 17, 24, March 2, 1844.

${ }^{55}$ Photocopy, Leffler, March 30, 1844, to Penrose. Captain Irish has not been identified.

${ }^{56}$ Photocopy, Leffler, June 6, 17, 1844, to Penrose. Dr. L. W. Hickok was one of nine physicians practicing in Burlington. See J. B. Newhall, A Glimpse of Iowa in 1846, or The Emigrant's Guide (Burlington: W. D. Skillman, 1846). This second edition was reprinted by the State Historical Society of Iowa in 1957. See p. 70.

${ }^{57}$ Photocopy, Chambers, June 25, 1844, to Penrose. For Marshal Johnson, see footnote 52. The background and career of Jeremiah Smith, Senior demands additional research, a project in which Jordan is engaged.

${ }^{58}$ Block 165 , lot 3 , grave 4 . The original headstone has been replaced by a more modern monument. Legends on other stones are not decipherable. Some graves are no longer marked, although outlines are discernable. Two members of the Potts family, relatives of Ellen Potts Smith (Mrs. Jeremiah Smith, Jr.) are buried on the lot.

${ }^{59}$ Taylor, "Before and After the Territorial Organization of Iowa," 451; Burlington Weekly Telegraph, March 6, 1852.

${ }^{\circ 0}$ The children were Amelia, Samuel, Iowa A., Jeremiah L., Adriadna, William H., George F., and Etna Ann. On March 17, 1852, William H. Smith was appointed guardian of Amelia, Samuel, and Iowa A., all under age fourteen. Revised Probate Index 1, p. 556, Guardianship of Minor Heirs of Jeremiah Smith, [Jr.], Clerk of District Court, Des Moines County. On May 31, William H. Smith was named executor of his father's estate. The widow, Ellen Potts Smith, died at her residence, 104 North Marshal Street, August 29, 1885. For obituary, see Burlington Hawk-Eye, August 30, 1885.

${ }^{61}$ Inventory of the Estate of Jer. Smith, Jr., Deceased, filed February 5, 1853, Office of County Judge, Clerk of District Court, Des Moines County. 
Copyright of Annals of Iowa is the property of State of Iowa, by \& through the State Historical Society of Iowa and its content may not be copied or emailed to multiple sites or posted to a listserv without the copyright holder's express written permission. However, users may print, download, or email articles for individual use. 